\title{
Can chlorophyll fluorescence be used to estimate the rate of photosynthetic electron transport within microphytobenthic biofilms?
}

\author{
R. G. Perkins, K. Oxborough*, A. R. M. Hanlon, G. J. C. Underwood, N. R. Baker \\ Department of Biological Sciences, University of Essex, Wivenhoe Park, Colchester, Essex CO4 3SQ, United Kingdom
}

\begin{abstract}
Chlorophyll fluorometry has frequently been used to estimate the photosynthetic electron transport rate (ETR) within oxygenic organisms. One of the requirements of this method is that the absorptivity of the photosynthetic system is known. In the specific case of microphytobenthos within biofilms, it is known that cells migrate vertically over relatively short time periods. This can radically alter the absorptivity of the photosynthetic biomass as a whole and, potentially, could result in highly inaccurate values of ETR being calculated. In this study, both modulated, integrating fluorometry and high resolution imaging of fluorescence have been used to investigate the error introduced into the calculation of ETR by the vertical migration of cells. Estimates of ETR derived from fluorescence data were compared with rates of primary production measured using a ${ }^{14} \mathrm{C}$-radiotracer method. The effect of fluorescence from photosystem I (PS I) on the calculated value of ETR was also assessed. Overall, these data suggest that PS I fluorescence can introduce significant errors into the estimation of ETR from diatom cultures and in the estimation of ETR from individual cells at the biofilm surface, when using high resolution imaging of chlorophyll fluorescence. Measurements made on intact biofilms under incident light showed an extremely poor correlation between estimated ETR (derived from fluorescence data) and primary production (measured by ${ }^{14} \mathrm{C}$ incorporation). The simplest explanation for this result is that the downward migration of cells decreased the amount of light absorbed by the photosynthetic biomass, which led to substantial errors in the calculation of ETR. The clear implication is that conventional (integrating) fluorometers cannot be used to determine rates of ETR from intact, migratory biofilms and that any realistic estimation of ETR within intact biofilms is likely to involve high resolution imaging of fluorescence.
\end{abstract}

KEY WORDS: Fluorescence imaging $\cdot$ Diatoms $\cdot$ Photosystem II $\cdot$ Photosystem I fluorescence $\cdot$ ETR Resale or republication not permitted without written consent of the publisher

\section{INTRODUCTION}

Microphytobenthic biofilms in estuarine sediments exhibit high rates of primary production (Underwood \& Kromkamp 1999), contribute to sediment stability (Paterson 1989, Underwood \& Paterson 1993, Yallop et al. 1994) and directly affect nutrient fluxes across the sediment-water interface (Thornton et al. 1999, Dong et al. 2000). One adaptation to the sediment habitat exhibited by benthic diatoms is to migrate vertically in

*Corresponding author. E-mail: koxbor@essex.ac.uk response to diurnal and tidal rhythms (Serôdio et al. 1997, Underwood \& Kromkamp 1999). Downward migration reduces wash-away of cells during immersion and grazing by predators and may increase nutrient availability (Decho 1990). Migration may also occur as a response to changes in ambient PPFD (for abbreviations used, see Table 1) and hence act as a behavioural method of photoacclimation (Paterson et al. 1998, Underwood \& Kromkamp 1999).

The application of chlorophyll fluorometry as a noninvasive technique for the estimation of photosynthetic efficiency in algae, including microphytobenthos, has increased in recent years (Serôdio et al. 1997, Hartig et 
Table 1. Abbreviations

\begin{tabular}{|ll|}
\hline$\alpha$ & Initial slope of the relationship between PPFD and ETR \\
$E_{\mathrm{k}}$ & Light saturation parameter \\
$\mathrm{ETR}$ & Electron transport rate \\
$\mathrm{ETR}$ & Maximum electron transport rate \\
$F^{\prime}$ & Chlorophyll fluorescence signal in the light-adapted state \\
$F_{\mathrm{m}}{ }^{\prime}$ & Chlorophyll fluorescence signal when all PS II centres are closed in the light-adapted state \\
$F_{\mathrm{q}}{ }^{\prime}$ & Difference between $F^{\prime}$ and $F_{\mathrm{m}}{ }^{\prime}$ \\
$F_{\mathrm{q}}{ }^{\prime} / F_{\mathrm{m}}{ }^{\prime}$ & Fluorescence parameter that provides an estimate of the operating efficiency of PS II photochemistry \\
$\phi_{\mathrm{CO}}$ & Quantum yield of CO2 assimilation \\
$\mathrm{PPFD}$ & Photosynthetically active photon flux density \\
\hline
\end{tabular}

al. 1998, Kromkamp et al. 1998, Underwood et al. 1999). Estimates of the photosynthetic electron transport rate (ETR) from fluorescence data have been compared with estimates of primary production, using ${ }^{14} \mathrm{C}$ radiotracers (Hartig et al. 1998, Wolfstein \& Hartig 1998, Barranguet \& Kromkamp 2000), and $\mathrm{O}_{2}$ evolution (Flameling \& Kromkamp 1998). In such studies, the so-called 'Genty factor' (Genty et al. 1989) has been used in estimation of the ETR. This factor provides an estimate of the proportion of absorbed photons that are used to drive photochemistry at PS II (the PS II operating efficiency) and is expressed (in the terminology used here) as the fluorescence parameter, $F_{\mathrm{q}}{ }^{\prime} / F_{\mathrm{m}}{ }^{\prime}$. This method of estimating ETR requires accurate measurement of both the incident PPFD and absorptivity of the sample. It also assumes that the photons absorbed are divided equally between PS II and PS I and that the value of $F_{\mathrm{q}}{ }^{\prime} / F_{\mathrm{m}}{ }^{\prime}$ provides a good estimate of the photon yield of electron transfer into the photosynthetic electron transport chain.

In most situations, errors in the measurement of PPFD and/or absorptivity and/or an uneven distribution of absorbed photons between PS II and PS I will result in proportional errors in the calculation of ETR. That is to say, while the calculated values of the initial slope $(\alpha)$ of the relationship between PPFD and calculated ETR and the maximum rate of ETR (ETR max $_{\text {mill }}$ both be inaccurate, the shape of the relationship between PPFD and ETR (and the value of $E_{\mathrm{k}}$ ) will not be affected. One way in which a non-proportional error (which will affect the shape of the relationship between PPFD and ETR) could be introduced is if the absorptivity of the sample changed with PPFD. Among the objectives of this study was to determine the extent to which the vertical migration of diatoms within biofilms might affect the absorptivity of the photosynthetic biomass as a whole. This part of the study employed high-resolution imaging of chlorophyll fluorescence (Oxborough \& Baker 1997, Oxborough et al. 2000), which makes it possible to assess the species composition and cell density at the surface of the biofilm at the same time that measurements of $F_{\mathrm{q}}{ }^{\prime} / F_{\mathrm{m}}{ }^{\prime}$ are being made.
The relationship between $F_{\mathrm{q}}{ }^{\prime} / F_{\mathrm{m}}{ }^{\prime}$ and the true value of the PS II operating efficiency can be affected by fluorescence from PS I (Genty et al. 1990, Pfündel 1998). The fluorescence yield of PS I is thought to be reasonably constant and independent of PPFD (Dau 1994, Pfündel 1998). In contrast, the fluorescence yield of PS II is known to be affected by 2 processes: PS II photochemistry, which results in photochemical quenching, and down-regulation, which results in non-photochemical quenching. Down-regulation, which tends to increase with PPFD, decreases the yield of fluorescence at $F_{\mathrm{m}}{ }^{\prime}$, while the combined effect of down-regulation and photochemistry result in a reasonably stable value of $F^{\prime}$ with changes in PPFD (Havaux et al. 1991, Genty et al. 1992, Laisk et al. 1997, Oxborough \& Baker 2000). Consequently, the relative effect of PS I fluorescence on the value of $F_{\mathrm{q}}{ }^{\prime} / F_{\mathrm{m}}{ }^{\prime}$ might be expected to increase with PPFD, introducing a non-proportional error into the relationship between PPFD and estimated values of ETR.

Data from a number of studies show a strong linear relationship between the value of $F_{\mathrm{q}}{ }^{\prime} / F_{\mathrm{m}}{ }^{\prime}$ and the quantum yield of $\mathrm{CO}_{2}$ assimilation $\left(\phi_{\mathrm{CO}_{2}}\right.$ ) (Genty et al. 1989, 1990, di Marco et al. 1990, Krall \& Edwards 1990, Edwards \& Baker 1993). This would seem to indicate that, in leaves of higher plants at least, PS I fluorescence frequently does not contribute enough to the overall fluorescence signal to induce a significant nonproportional error of the type just described. Another objective of this study was to determine whether or not PS I fluorescence introduces a significant nonproportional error into the estimation of ETR from intact biofilms. This was achieved by comparing fluorescence data that were collected using 1 of 2 different filters in front of the fluorescence detector. The first of these (680 nm bandpass) filters out most of the PS I fluorescence, resulting in a very high PS II to PS I fluorescence ratio, while the second (a $695 \mathrm{~nm}$ longpass) allows a much higher proportion of PS I fluorescence to pass through while filtering out a proportion of PS II fluorescence, resulting in a substantially lower PS II to PS I fluorescence ratio. If the contribution of PS I fluorescence to the overall signal is high enough to introduce a non-proportional error, this would be expected 
to show up as a difference between the estimated values of ETR, derived from the measurements, which increases with PPFD.

Finally, values of ETR, estimated from fluorescence data, were compared with rates of primary production, as measured by a ${ }^{14} \mathrm{C}$-radiotracer method. Measurements were made on intact biofilms over a $14 \mathrm{~h}$ period to allow for an assessment of the comparative effects of diel and tidal rhythms on these parameters.

\section{MATERIALS AND METHODS}

Diatom cultures. Cultures of Cylindrotheca closterium, (Ehr.) Reimann et Lewin. were grown at a PPFD of $180 \mu \mathrm{mol} \mathrm{m} \mathrm{m}^{-2} \mathrm{~s}^{-1}$ on a 14/10 h light/dark cycle at $18^{\circ} \mathrm{C}$ in a growth cabinet using $\mathrm{f} / 2$ media (Guillard \& Ryther 1962), salinity 20 and with an added antibiotic cocktail to inhibit bacterial growth (Smith \& Underwood 1998). Stationary phase was reached on Day 5. Fluorescence measurements were made during the logarithmic phase, on Days 3 and 4.

Sampling of intact biofilms. Microphytobenthic biofilms were sampled at low tide using $7.5 \mathrm{~cm}$ diameter cores: from 2 sites in the Colne estuary, Alresford Creek (51 $\left.50.2^{\prime} \mathrm{N}, 0^{\circ} 59.5^{\prime} \mathrm{E}\right)$ and The Hythe (51 $52.5^{\prime} \mathrm{N}$, $\left.0^{\circ} 56.2^{\prime} \mathrm{E}\right)$, Colchester, Essex, UK. Alresford Creek is situated midway along the estuarine salinity gradient and supports diatom-dominated biofilms with some euglenoids. The Hythe is at the head of the estuary, with a low salinity range and high nutrient concentrations, and is dominated by euglenoids with some cyanobacteria and diatoms (Underwood et al. 1998). Cores were carefully transported back to the laboratory and maintained in shallow trays containing site water to prevent drying of the sediment surface. Light response curves, from intact cores, were started within $2 \mathrm{~h}$ of sampling and within the low tide period (when the sediments would not have been immersed). Comparison of ${ }^{14} \mathrm{C}$-radiotracer and fluorescence measurements were started the day after sampling. All samples were taken during July 1999, when the ambient temperature was between 22 and $25^{\circ} \mathrm{C}$.

Measurements of chlorophyll fluorescence from cultures and intact biofilms. The fluorescence terminology employed here is the same as used by Oxborough et al. (2000). Chlorophyll fluorescence was measured using a Xenon PAM fluorometer (Walz $\mathrm{GmbH}$, Effeltrich, Germany) or a high resolution fluorescence imaging system (Oxborough \& Baker 1997, Oxborough et al. 2000). With the PAM system, the saturating pulses used for measurement of $F_{\mathrm{m}}$ ' were at a PPFD of $8600 \mu \mathrm{mol} \mathrm{m} \mathrm{m}^{-2} \mathrm{~s}^{-1}$ for $300 \mathrm{~ms}$. With the imaging system $F_{\mathrm{m}}{ }^{\prime}$ was imaged over the last $100 \mathrm{~ms}$ of a $350 \mathrm{~ms}$ saturating pulse at a PPFD of $8100 \mu \mathrm{mol} \mathrm{m} \mathrm{m}^{-2} \mathrm{~s}^{-1}$. With both the PAM and imaging systems, chlorophyll fluorescence was defined by either a $680 \mathrm{~nm}$ bandpass filter (Coherent, Watford, UK) or an RG 695 longpass filter (Schott, Mainz, Germany). One complication that arises in comparing data from measurements using the 2 filters is that fluorescence of shorter wavelengths (between approximately 675 and $685 \mathrm{~nm}$ ) is strongly reabsorbed, because these wavelengths are close to the peak of the chl a absorption spectrum. Consequently, use of the $680 \mathrm{~nm}$ filter could, in principle, decrease the measured value of $F_{\mathrm{q}}{ }^{\prime} / F_{\mathrm{m}}$ ' from relatively dense systems (such as leaves or dense biofilms) because fluorescence from the cells at depth will be reabsorbed by the cells at the surface (which will normally be operating at a lower efficiency, because they are absorbing more light than the underlying cells).

A detailed description of the high resolution imaging system used in this study is given in Oxborough \& Baker (1997). The method used to isolate individual cells from images is described in Oxborough et al. (2000). Integrated values of $F_{\mathrm{q}}{ }^{\prime} / F_{\mathrm{m}}{ }^{\prime}$ across whole images were calculated by summing all values within the $F^{\prime}$ and $F_{\mathrm{m}}$ ' images used and then calculating a single mean value. Values of $F_{\mathrm{q}}{ }^{\prime} / F_{\mathrm{m}}{ }^{\prime}$ from isolated cells were calculated as the sum of individual pixel values for this parameter (Oxborough \& Baker 1997).

Estimation of ETR, ETR max $\boldsymbol{\alpha}$ and $\boldsymbol{E}_{\mathrm{k}}$. ETR was estimated according to the method of Sakshaug et al. (1997), which is essentially the same as the method originally described within the Walz PAM 2000 fluorometer handbook. In Eq. (1), $a^{*}$ is the specific absorption coefficient for $\mathrm{chl} a$. Values of $a^{*}$ were determined using an integrating sphere and cosine-corrected light meter. Biofilms were sampled using the lens tissue technique (Eaton \& Moss 1966). Cells were re-suspended in f/2 media in repli-dishes (Bibby Sterlin). This was serially diluted to construct a standard curve of absorption versus chl a concentration (over a range of 50 to $800 \mathrm{~g} \mathrm{l}^{-1}$ ), from which $a^{*}$ could be determined.

$$
\mathrm{ETR}=\frac{F_{\mathrm{q}}{ }^{\prime}}{F_{\mathrm{m}}{ }^{\prime}} \cdot \frac{\mathrm{PPFD}}{2} \cdot a^{*}
$$

Values for the maximum ETR $\left(\mathrm{ETR}_{\max }\right)$, light utilisation coefficient $(\alpha)$ and the light saturation parameter $\left(E_{\mathrm{k}}=\right.$ $\mathrm{ETR}_{\max } / \alpha$ ) were determined through iteration (Long \& Hällgren 1993), from light response curves (ETR vs PPFDs of 40 to $920 \mu \mathrm{mol} \mathrm{m} \mathrm{m}^{-2} \mathrm{~s}^{-1}$ ).

Comparison of ${ }^{14} \mathrm{C}$-radiotracer and fluorescence measurements. Sample cores were collected from Alresford Creek, as above, on July 15 and 22, 1999, and incubated the following day in a temperature-controlled glasshouse $\left(22^{\circ} \mathrm{C}\right)$. Light curves were obtained hourly, using the PAM system, between 06:00 and 20:00 h. In addition, values of $F_{\mathrm{q}}{ }^{\prime} / F_{\mathrm{m}}{ }^{\prime}$ were determined from measurements made with the PAM system under 
ambient PPFD every hour and at a PPFD of $220 \mu \mathrm{mol} \mathrm{m} \mathrm{m}^{-2} \mathrm{~s}^{-1}$ with the high resolution imaging system). The $680 \mathrm{~nm}$ bandpass filter was used in both cases. Ambient PPFD was logged every $10 \mathrm{~min}$ and hourly averages used in calculations. Fluorescence data were compared to bi-hourly measurements of $\mathrm{CO}_{2}$ incorporation using the ${ }^{14} \mathrm{C}$-radiotracer method.

For the measurements of $\mathrm{CO}_{2}$ incorporation, $1 \mathrm{ml}$ of ${ }^{14} \mathrm{C}$-labelled sodium bicarbonate $(370 \mathrm{kBq})$ was added to minicores (internal area $3.14 \mathrm{~cm}^{2}$ ) taken from each large core. This was allowed to diffuse into the biofilm during a $1 \mathrm{~h}$ dark period, which was followed by $1 \mathrm{~h}$ incubation under ambient PPFD, terminated by the addition of gluteraldehyde $(5 \% \mathrm{v} / \mathrm{v})$. The surface $2 \mathrm{~mm}$ of biofilm was carefully sliced off and freeze-dried. Hydrochloric acid was added to drive off inorganic label. After the addition of scintillant cocktail

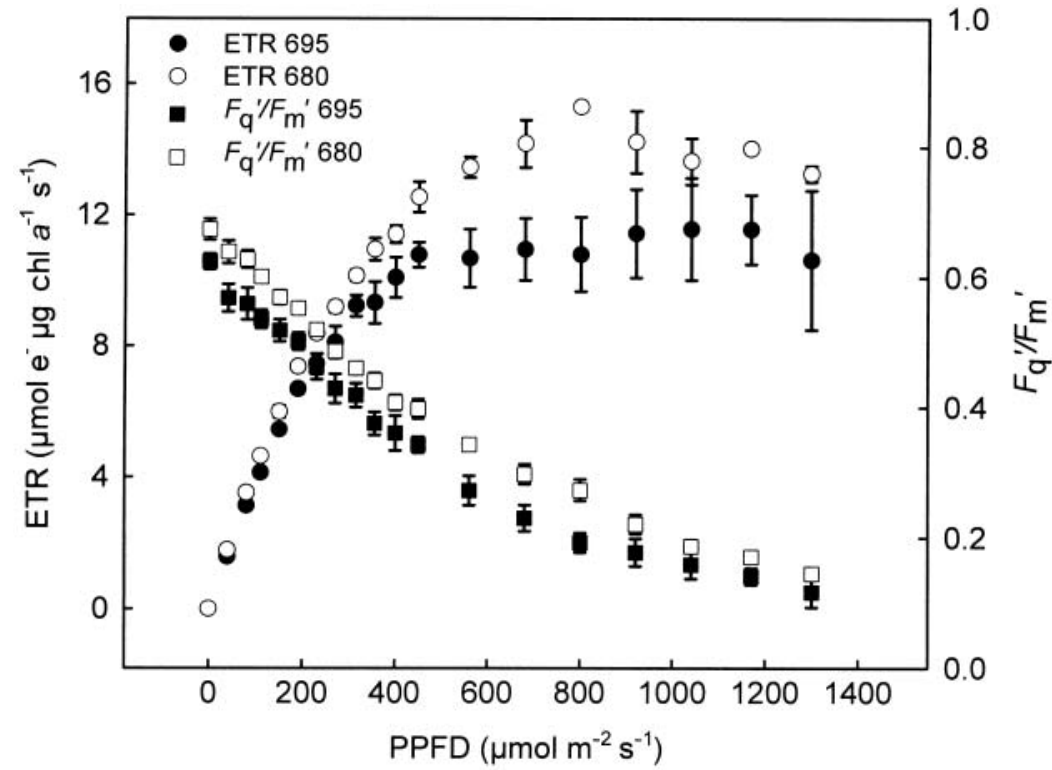

Fig. 1. Comparison of values (mean $\pm \mathrm{SE}, \mathrm{n}=3$ ) for $F_{\mathrm{q}}{ }^{\prime} / F_{\mathrm{m}}{ }^{\prime}$ and estimated $\mathrm{ETR}$, derived from measurements of chlorophyll fluorescence from cultures of Cylindrothea closterium. Measurements were made using a Xenon PAM fluorometer, with the $680 \mathrm{~nm}$ bandpass filter or the $695 \mathrm{~nm}$ longpass filter
(Optiphase Safe, Fisons, Loughborough,

$\mathrm{UK})$, rates of $\mathrm{CO}_{2}$ incorporation were calculated from counts obtained from a Packard Tricarb 460C scintillation counter with internal quench correction. Counts were corrected for self-quenching by the sediment using radiation standard curves, with and without sediment addition. Self-quenching reduced counts by less than $5 \%$. Rates of $\mathrm{CO}_{2}$ incorporation were corrected for dark uptake using dark controls (Smith \& Underwood 1998). Paired measurements of chl a were made for each core. For spectrophotometric determination, chl a was extracted in cold methanol and samples were acidified to correct for phaeopigments (Lorenzen 1967).

Table 2. Comparison of electron transport parameters derived from measurements of chlorophyll fluorescence made using either a $680 \mathrm{~nm}$ bandpass filter or $695 \mathrm{~nm}$ longpass filter. Some of the original data that were used to calculate the values in this table are shown in Figs. $1 \& 2$

\begin{tabular}{|c|c|c|c|}
\hline Filter/Site & $\begin{array}{l}\text { Estimated ETR } \text { max }_{\text {max }} \\
\qquad \begin{array}{c}\left(\mu \mathrm{mol} \mathrm{e}^{-} \mu \mathrm{g}\right. \\
\left.\operatorname{chl} a^{-1} \mathrm{~s}^{-1}\right)\end{array}\end{array}$ & $\begin{array}{cc}\alpha \\
\left.\text { chl } a^{-1} \mu \mathrm{mol}^{-} \text {photons }^{-1}\right)\end{array}$ & $\begin{array}{c}E_{\mathrm{k}} \\
(\mu \mathrm{mol} \text { photons } \\
\left.\mathrm{m}^{-2} \mathrm{~s}^{-1}\right)\end{array}$ \\
\hline \multicolumn{4}{|c|}{ Cylindrotheca closterium, PAM fluorometer } \\
\hline $680 \mathrm{~nm} /$ culture & $14.3 \pm 0.68$ & $0.037 \pm 0.0003$ & 390 \\
\hline $695 \mathrm{~nm} /$ culture & $11.5 \pm 0.35$ & $0.037 \pm 0.0040$ & 310 \\
\hline \multicolumn{4}{|c|}{ Measurements made using the high resolution imaging system } \\
\hline $680 \mathrm{~nm} /$ Alresford & $10.0 \pm 0.46$ & $0.024 \pm 0.0022$ & 420 \\
\hline $695 \mathrm{~nm} /$ Alresford & $9.8 \pm 0.67$ & $0.027 \pm 0.0028$ & 360 \\
\hline $680 \mathrm{~nm} /$ Hythe & $7.1 \pm 0.00$ & $0.021 \pm 0.0030$ & 340 \\
\hline 695 nm/Hythe & $4.5 \pm 0.10$ & $0.028 \pm 0.0020$ & 160 \\
\hline
\end{tabular}

\section{RESULTS}

\section{Effect of PS I fluorescence on the estimated value of ETR}

The light response curves in Fig. 1 illustrate the effect of removing most of the PS I fluorescence from the overall fluorescence signal (by using the $680 \mathrm{~nm}$ bandpass filter, instead of the $695 \mathrm{~nm}$ longpass filter) on $F_{\mathrm{q}}{ }^{\prime} / F_{\mathrm{m}}{ }^{\prime}$ and the estimated value of ETR from cultures of Cylindrotheca closterium. Values of $F_{\mathrm{q}}{ }^{\prime} / F_{\mathrm{m}}{ }^{\prime}$ were significantly higher throughout the light curve when the $680 \mathrm{~nm}$ bandpass filter was used $\left(F_{2(1,56)}=\right.$ $97.4, \mathrm{p}<0.001)$. Because these cultures had a very short optical path, the re-absorption of fluorescence by overlying cells (discussed in 'Methods') was minimised and the effect of removing the PS I fluorescence was maximised. Between 0 and $900 \mu \mathrm{mol} \mathrm{m}{ }^{-2} \mathrm{~s}^{-1}$, the difference between the 2 sets of measurements increased with PPFD. At PPFDs $>900 \mu \mathrm{mol} \mathrm{m} \mathrm{m}^{-2} \mathrm{~s}^{-1}$, this difference in calculated rates of ETR levels off and even decreased slightly. ETR $\max$ was $24 \%$ higher with the $680 \mathrm{~nm}$ bandpass filter, compared to the $695 \mathrm{~nm}$ longpass filter. There was no significant difference in $\alpha$ between the 2 filters. Consequently, $E_{\mathrm{k}}$ was higher with the $680 \mathrm{~nm}$ bandpass filter. Values of 


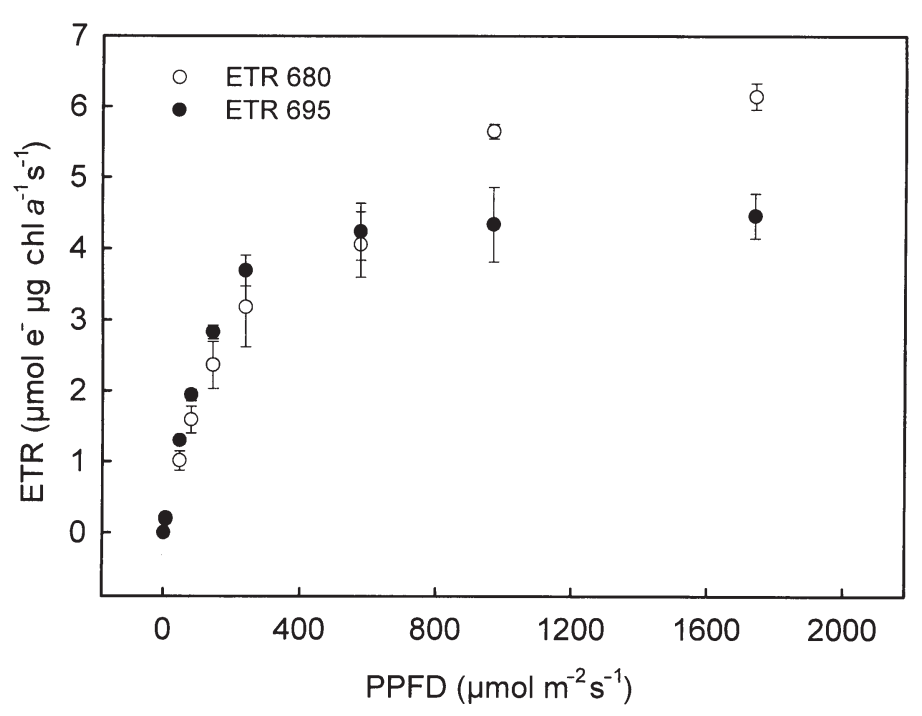

Fig. 2. Comparison of estimated ETR (mean $\pm \mathrm{SE}, \mathrm{n}=3$ ) derived from images of chlorophyll fluorescence from an intact biofilm sampled from The Hythe. Measurements were made using the $680 \mathrm{~nm}$ bandpass filter or the $695 \mathrm{~nm}$ longpass filter

$\mathrm{ETR}_{\max }, \alpha$ and $E_{\mathrm{k}}$ derived from these light response curves are shown in Table 2.

Similar calculated rates of ETR derived from light response curves from an intact biofilm, sampled from The Hythe, are shown in Fig. 2. These measurements were made using the high resolution imaging system. In contrast to the data from the cultures of Cylindrotheca closterium (Fig. 1), the estimated values of ETR using the $680 \mathrm{~nm}$ bandpass are actually lower than those using the $695 \mathrm{~nm}$ longpass filter between 0 and

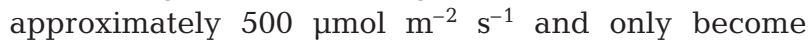
higher at PPFDs $>500 \mu \mathrm{mol} \mathrm{m} \mathrm{m}^{-2} \mathrm{~s}^{-1}$. This pattern of relative values of ETR with the 2 filters is reflected in

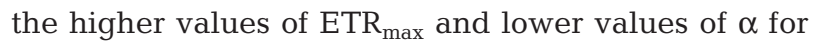
the $680 \mathrm{~nm}$ bandpass filters. Values of $\mathrm{ETR}_{\text {max }} \alpha$ and $E_{\mathrm{k}}$ derived from these light response curves are shown in Table 2, along with similar data collected from an intact biofilm sampled from the Alresford Creek site.

Selected fluorescence images (at $F^{\prime}$ ) used in the construction of the light response curves from Alresford Creek and The Hythe are shown in Fig. 3. At Alresford Creek, there was a very obvious decrease in the density of cells of Staurophora amphioxus at the surface of the biofilm with increasing PPFD, in combination with an overall decrease in cell density (Fig. 3a,c,e). At The Hythe, the surface of the biofilm was increasingly dominated by euglenoids with increasing PPFD (Fig. 3b,d,f), although the overall cell density did not change appreciably, due to the downward movement of diatoms (mainly Gyrosigma sp.). These changes in species composition occurred on the time scale of $10 \mathrm{~min}$ or less.
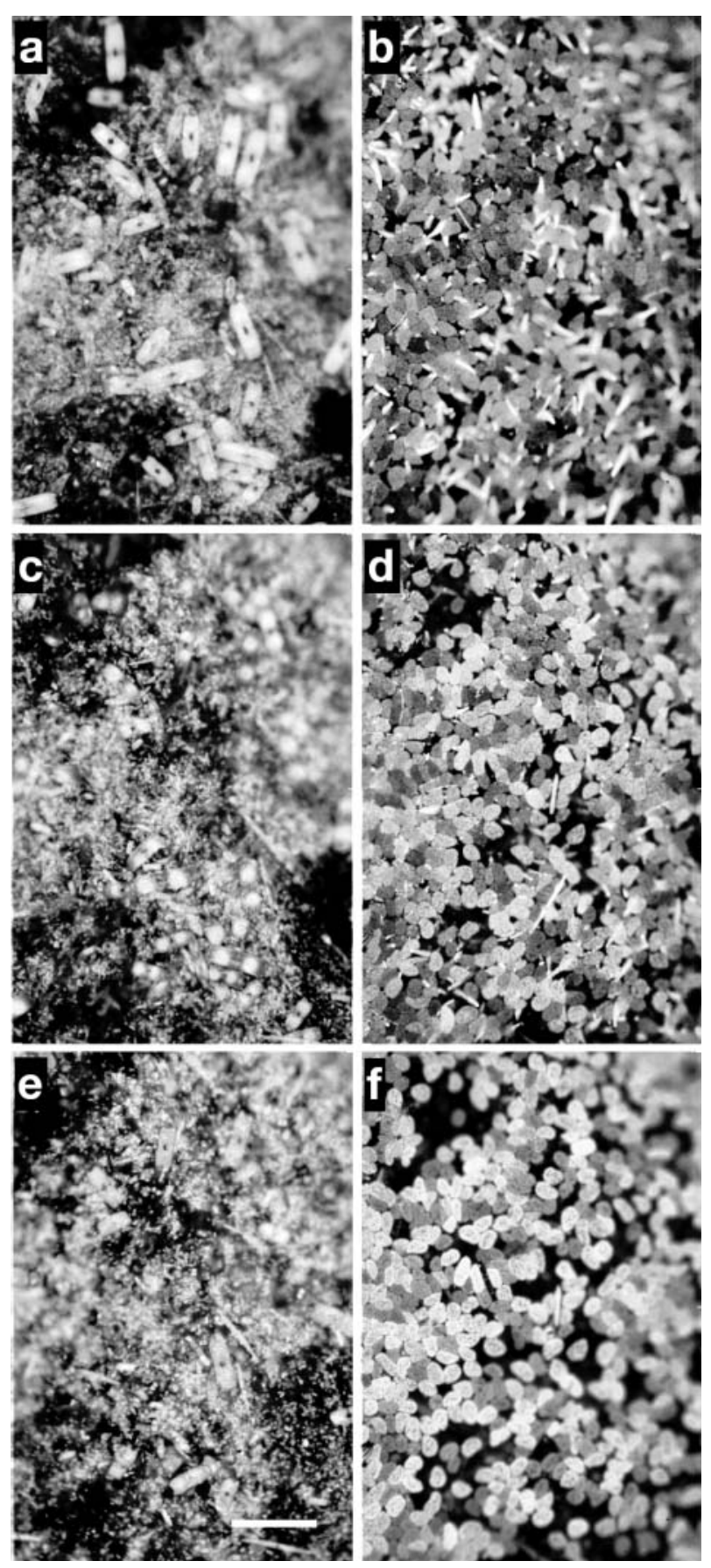

Fig. 3. Selected fluorescence images (at $F^{\prime}$ ) used in the construction of the light response curves from $(\mathrm{a}, \mathrm{c}, \mathrm{e})$ Alresford Creek and $(b, d, f)$ The Hythe. Images were taken at a PPFD of $180 \mu \mathrm{mol} \mathrm{m}{ }^{-2} \mathrm{~s}^{-1}(\mathrm{a}, \mathrm{b}), 380 \mu \mathrm{mol} \mathrm{m}{ }^{-2} \mathrm{~s}^{-1}(\mathrm{c}, \mathrm{d})$ or $1150 \mu \mathrm{mol} \mathrm{m}^{-2} \mathrm{~s}^{-1}$ $(\mathrm{e}, \mathrm{f})$. All images were taken using the $680 \mathrm{~nm}$ bandpass filter. Scale bar in (e) is $100 \mu \mathrm{m}$ long

The images in Fig. 4 illustrate the differences in $F_{\mathrm{q}}{ }^{\prime} / F_{\mathrm{m}}{ }^{\prime}$ for cells at the surface of biofilms taken from Alresford Creek or The Hythe, at a PPFD of 180 or $1150 \mu \mathrm{mol} \mathrm{m}{ }^{-2} \mathrm{~s}^{-1}$, when fluorescence was defined with the $680 \mathrm{~nm}$ band- 
pass or the $695 \mathrm{~nm}$ longpass filter. At the lower PPFD, the cells at the surface showed lower values of $F_{\mathrm{q}}{ }^{\prime} / F_{\mathrm{m}}{ }^{\prime}$ when the $680 \mathrm{~nm}$ bandpass filter was used, rather than the 695 nm longpass filter. Conversely, the $680 \mathrm{~nm}$ bandpass filter gave higher values of $F_{\mathrm{q}}{ }^{\prime} / F_{\mathrm{m}}{ }^{\prime}$, compared to the 695 $n m$ longpass filter, at the higher PPFD.
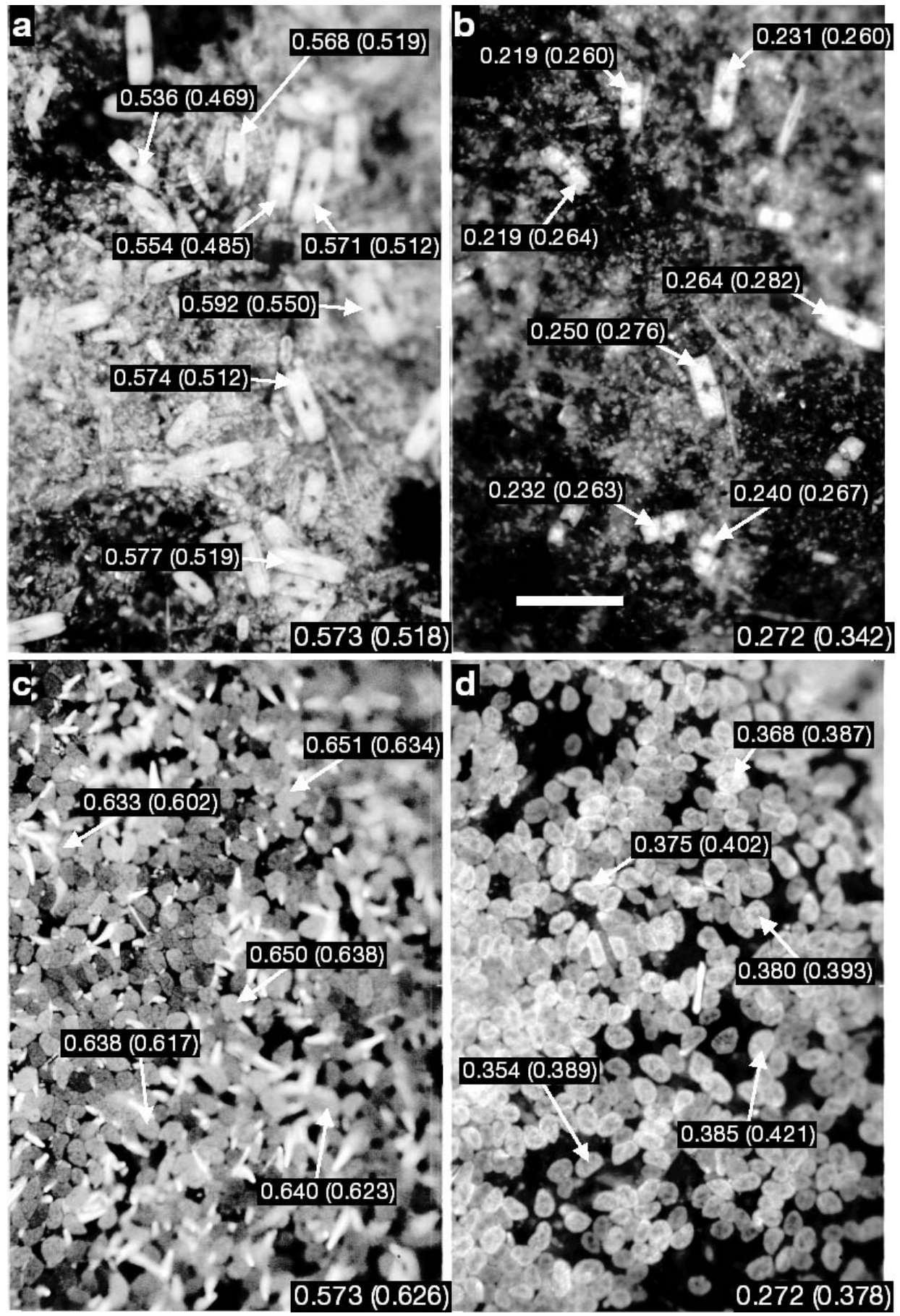

Fig. 4. Images of $F^{\prime}$ taken at a PPFD of $\left.180 \mu \mathrm{mol} \mathrm{m} \mathrm{m}^{-2} \mathrm{~s}^{-1} \mathrm{a}, \mathrm{c}\right)$ or $1150 \mu \mathrm{mol} \mathrm{m} \mathrm{m}^{-2} \mathrm{~s}^{-1}(\mathrm{~b}, \mathrm{~d})$. Images are from (a,b) Alresford Creek and $(\mathrm{c}, \mathrm{d})$ The Hythe and were taken using the $695 \mathrm{~nm}$ longpass filter. Numbers that accompany the arrows within images indicate the value of $F_{\mathrm{q}}{ }^{\prime} / F_{\mathrm{m}}$ ' for the cell to which the arrow is pointing. Numbers in the bottom right hand corner of each image are mean values for the whole image. In all cases, the initial value is calculated from images of $F^{\prime}$ and $F_{\mathrm{m}}$ ' taken using the $695 \mathrm{~nm}$ longpass filter while the numbers in brackets are from images of $F^{\prime}$ and $F_{\mathrm{m}}{ }^{\prime}$ taken using the $680 \mathrm{~nm}$ bandpass filter. Values of $F_{\mathrm{q}}{ }^{\prime} / F_{\mathrm{m}}{ }^{\prime}$ from individual cells were calculated using the method described in Oxborough et al. (2000). Scale bar in (b) is $100 \mu \mathrm{m}$ long 


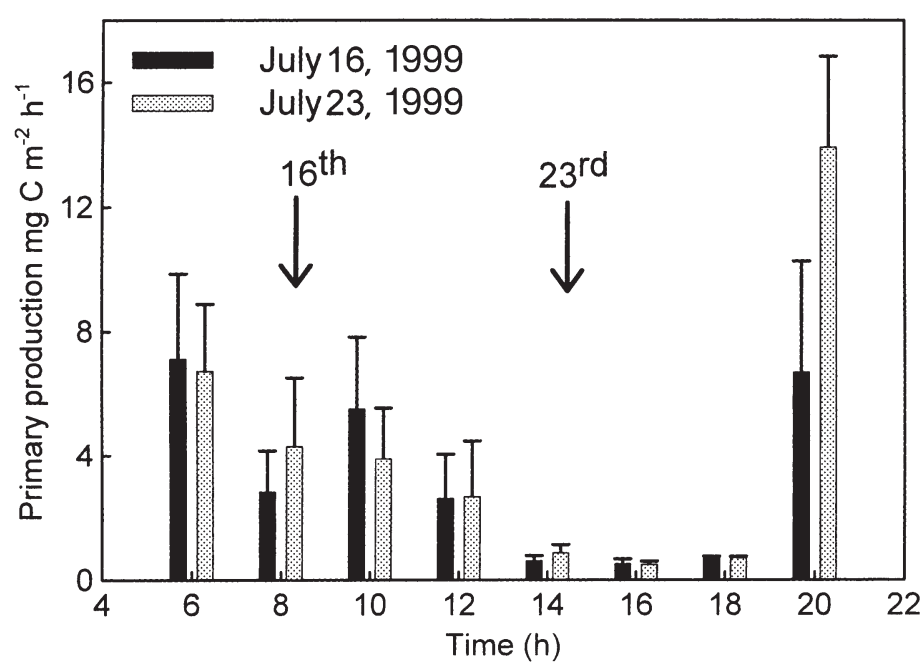

Fig. 5. Rates of primary production (mean $\pm \mathrm{SE}, \mathrm{n}=3$ ) followed using the ${ }^{14} \mathrm{C}$-radiotracer method. Intact biofilms were sampled from Alresford Creek on July 15 and 22, 1999. In both cases, measurements were made under greenhouse conditions over $16 \mathrm{~h}$ periods on the following day. Arrows indicate the time that the biofilms would have experienced low tide on the days that measurements were made ference between ${ }^{14} \mathrm{C}$ incorporation and calculated rates of ETR was most evident at 2 peaks in PPFD, at approximately 12:00 and 15:00 h (Fig. 6). At these points, the rate of ${ }^{14} \mathrm{C}$ incorporation was relatively low (particularly at 15:00 h) while the calculated rates of ETR were very high ( 2 to 3 times higher than at any other time). It is also noticeable that the very large increases in PPFD at 12:00 and 15:00 $\mathrm{h}$ were accompanied by increases in $F_{\mathrm{q}}{ }^{\prime} / F_{\mathrm{m}}{ }^{\prime}$.

Although the integrated values of $F_{\mathrm{q}}{ }^{\prime} / F_{\mathrm{m}}{ }^{\prime}$ under ambient PPFD did not correlate with rates of ${ }^{14} \mathrm{C}$ primary production, rates of primary production under ambient PPFD did correlate with values of $F_{\mathrm{q}}{ }^{\prime} / F_{\mathrm{m}}{ }^{\prime}$ measured from individual cells of Staurophora amphioxus and Pleurosigma angulatum at the surface of the biofilm, at a constant PPFD of $220 \mu \mathrm{mol} \mathrm{m} \mathrm{m}^{-2} \mathrm{~s}^{-1}$ ( $\mathrm{r}=$ 0.67, $\mathrm{p}<0.01, \mathrm{n}=21$ for $S$. amphioxus and $\mathrm{r}=0.92, \mathrm{p}<$ $0.01, \mathrm{n}=15$ for $P$. angulatum) (Fig. 7). Changes in the community structure of the biofilm were also observed. On July 16, the biofilm was dominated by $S$. amphioxus between 07:00 and 11:00 h. Thereafter $P$. angulatum and Gyrosigma spp. were more evident until 15:00 h, when the population became very mixed. By 18:00 h, S. amphioxus was again dominant.

\section{DISCUSSION}

\section{Effect of vertical migration of cells on the estimated value of ETR}

The rate of primary production by an intact biofilm from Alresford Creek was followed using the ${ }^{14} \mathrm{C}$-radiotracer method (Fig. 5). Measurements were made on emersed cores under glasshouse conditions over $16 \mathrm{~h}$ periods, between 06:00 and 22:00 h, on July 16 and 23. Measurements of $F_{\mathrm{q}}{ }^{\prime} / F_{\mathrm{m}}{ }^{\prime}$, estimated ETR and incident PPFD over the same $16 \mathrm{~h}$ period on July 16 are shown in Fig. 6. It is clear from the data in Fig. 5 that there was no obvious relationship between primary production and tide time, as the pattern of ${ }^{14} \mathrm{C}$ incorporation was very similar on both dates, even though the tide was roughly $6 \mathrm{~h}$ later on July 23. Nor did the rate of primary production correlate with PPFD, since the highest rates of ${ }^{14} \mathrm{C}$ incorporation (Fig. 5) were seen in the early morning and late evening, while the highest PPFDs were seen over the middle part of the day (Fig. 6).

The data in Figs. $5 \& 6$ also reveal that the rate of primary production did not correlate with the calculated values of ETR over the course of the day. The dif-
The simplest system examined here was the culture of Cylindrotheca closterium (Fig. 1). With such a system, the re-absorption of fluorescence from underlying

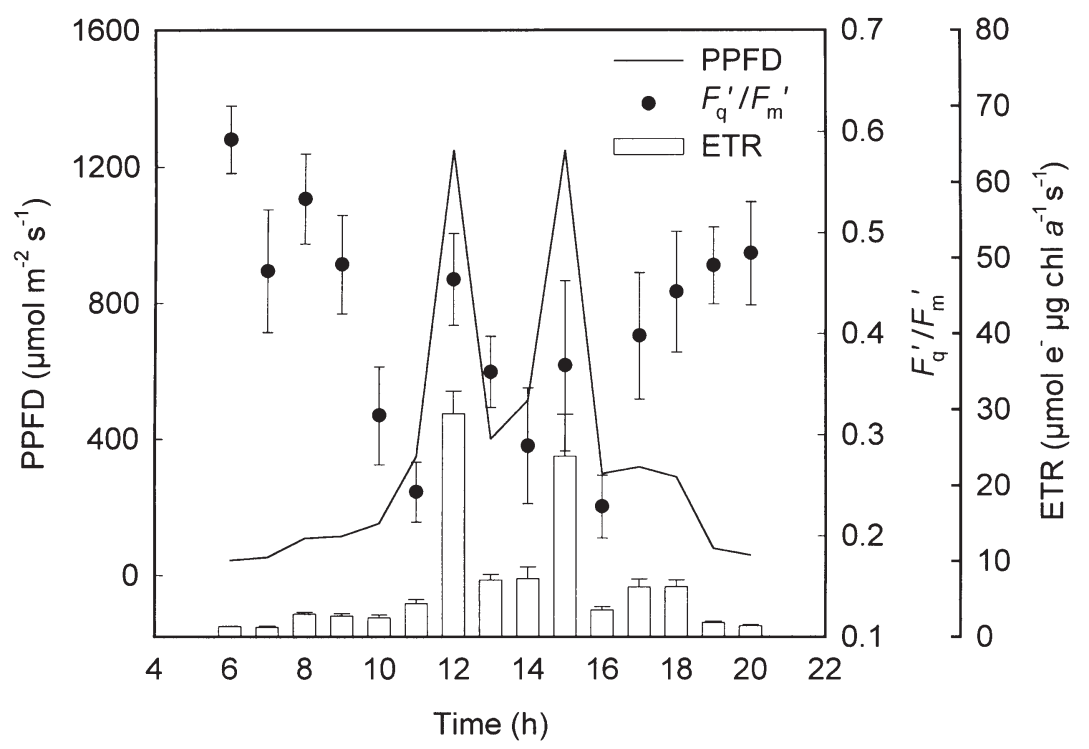

Fig. 6. Estimated values of ETR, values of $F_{\mathrm{q}}{ }^{\prime} / F_{\mathrm{m}}{ }^{\prime}$ and changes in ambient PPFD measured on July 16, 1999, from biofilm samples taken from Alresford Creek on the previous day. Measurements were made under greenhouse conditions. Rates of primary production from the same samples are shown in Fig. 5 


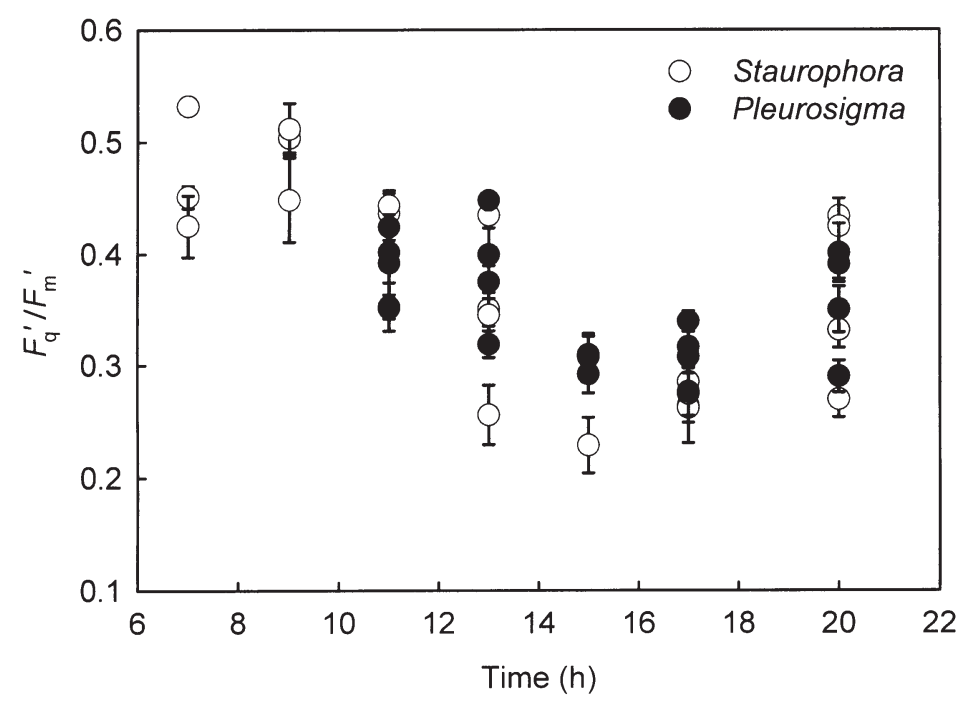

Fig. 7. Integrated values of $F_{\mathrm{q}}{ }^{\prime} / F_{\mathrm{m}}{ }^{\prime}$ from cells of Staurophora amphioxus and Pleurosigma angulatum that were present at the surface of biofilms sampled from Alresford Creek on July 15, 1999. Measurements were made using the high resolution imaging system at a constant PPFD of $220 \mu \mathrm{mol} \mathrm{m} \mathrm{m}^{-2} \mathrm{~s}^{-1}$ on July 16, 1999. Rates of primary production, estimated values of ETR, values of $F_{\mathrm{q}}{ }^{\prime} / F_{\mathrm{m}}{ }^{\prime}$ and changes in ambient PPFD made from the same biofilm samples under glasshouse conditions on the same day are shown in Figs. $5 \& 6$

cells is minimal and there is a clear advantage to removing most of the PS I fluorescence by using the $680 \mathrm{~nm}$ bandpass filter, rather than the $695 \mathrm{~nm}$ longpass filter. With intact biofilms the situation is more complex, since the $680 \mathrm{~nm}$ bandpass filter removes most of the PS I fluorescence but also decreases the fraction of the total fluorescence signal coming from the cells at depth within the biofilm. In many instances, the cells deeper within the biofilm have a higher PS II operating efficiency. Consequently, the re-absorption of a proportion of the fluorescence signal from these cells can actually decrease the overall, integrated value of this parameter.

The light curves in Fig. 2 and light curve data in Table 2 show that the overall effect of using the $680 \mathrm{~nm}$ bandpass filter, rather than the $695 \mathrm{~nm}$ longpass filter, is to increase the estimated values of $\mathrm{ETR}_{\max }$ and $E_{\mathrm{k}}$ while decreasing the value of $\alpha$. These data suggest that in these instances the increase in $F_{\mathrm{q}}{ }^{\prime} / F_{\mathrm{m}}{ }^{\prime}$ resulting from the removal of most of the PS I fluorescence when the $680 \mathrm{~nm}$ bandpass filter is used is more than offset by the removal of part of the fluorescence signal from the cells at depth at low to moderate PPFDs, but not at high PPFDs. Clearly, these data illustrate that use of the $680 \mathrm{~nm}$ bandpass filter, rather than the $695 \mathrm{~nm}$ longpass filter, has a non-proportional effect on the relationship between PPFD and estimated ETR. However, it is equally clear that neither filter is providing an accurate picture of the true relationship between these parameters and that, in the context of integrated fluorescence measurements, there is no clear advantage to using either filter.

The images in Fig. 4 illustrate the dual effects of decreasing PS I fluorescence and background fluorescence through use of the $680 \mathrm{~nm}$ bandpass filter, rather than the $695 \mathrm{~nm}$ longpass filter. At the lower PPFD of $180 \mu \mathrm{mol} \mathrm{m}{ }^{-2} \mathrm{~s}^{-1}, F_{\mathrm{q}}{ }^{\prime} / F_{\mathrm{m}}{ }^{\prime}$ was lower when the $680 \mathrm{~nm}$ bandpass filter was used while at the higher PPFD of $1150 \mu \mathrm{mol} \mathrm{m}{ }^{-2} \mathrm{~s}^{-1}$ the situation was reversed. This was true for cells isolated from the surface of both biofilms and for the integrated values. The most obvious explanation for these results is that, at low PPFD, the increase in $F_{\mathrm{q}}{ }^{\prime} / F_{\mathrm{m}}$ ' due to the removal of PS I fluorescence by the $680 \mathrm{~nm}$ bandpass filter is more than offset by the decrease in $F_{\mathrm{q}}{ }^{\prime} / F_{\mathrm{m}}{ }^{\prime}$ due to the removal of fluorescence from deep within the biofilm, while at high PPFD, the removal of PS I fluorescence has more effect on the overall value of $F_{\mathrm{q}}{ }^{\prime} / F_{\mathrm{m}}{ }^{\prime}$ than does the removal of fluorescence from deep within the biofilm. It is these competing effects of the $680 \mathrm{~nm}$ bandpass filter on $F_{\mathrm{q}}{ }^{\prime} / F_{\mathrm{m}}{ }^{\prime}$ that result in the complex relationship between PPFD and estimated ETR that is revealed by the data in Fig. 2 and Table 2.

Although PS I fluorescence clearly introduces an error into the calculation of ETR (through $F_{\mathrm{q}}{ }^{\prime} / F_{\mathrm{m}}{ }^{\prime}$ ), this error is minor compared to the size of the error that can result from the vertical migration of cells and (to a lesser extent) changes in species composition at the surface of biofilms. Of particular note are the large increases in the estimated values of ETR that were observed at 12:00 and 15:00 h on July 16 (Fig. 6). These data are almost certainly due to the migration of cells deeper into the sediment at high PPFD, which has greatly reduced the proportion of incident photons that are actually absorbed by the cells and which has resulted in values of $F_{\mathrm{q}}{ }^{\prime} / F_{\mathrm{m}}$ ' that are higher than those on either side of the peaks. Since the change in absorptivity of the cells is not taken into account (and cannot realistically be accounted for when using an integrating fluorometer system) the estimated value of ETR is very much higher than the true value.

Previous studies have assessed the relationship between ETR and rates either of ${ }^{14} \mathrm{C}$ assimilation or $\mathrm{O}_{2}$ evolution using slurries (Hartig et al. 1998, Wolfstein \& Hartig 1998, Barranguet \& Kromkamp 2000). With slurry systems, the cells are suspended in a light environment that is radically different from that experienced within the intact biofilm (Underwood \& Kromkamp 1999) and obviously take no account of the impact of vertical migration on the fraction of incident light that is actually absorbed. Clearly, imaging of chlorophyll fluorescence provides a powerful method for assessing vertical migration within intact biofilms. 
The rate of primary production measured by ${ }^{14} \mathrm{C}$ radiotracer (Fig. 5) showed a diel pattern that was independent of PPFD or tidal rhythm. The observation that this pattern correlated significantly with $F_{\mathrm{q}}{ }^{\prime} / F_{\mathrm{m}}{ }^{\prime}$ measured from individual cells at the biofilm surface, at constant PPFD (Fig. 7), suggests that some form of endogenous rhythm may be operating at the cell level. Although $\mathrm{pH}$-mediated changes of the $\mathrm{CO}_{2}$ equilibrium would effect the ${ }^{14} \mathrm{C}$-specific activity within biofilms and could account for apparent decreases in the calculated rate of primary production, this does not seem to be the case here. pH-mediated shifts will be most apparent in dense biofilms under high irradiance (Underwood \& Kromkamp 1999). However, we have consistently measured similar significant patterns of high morning rates of primary production in biofilms from a range of sites and sampled at different times of the year, independent of biofilm biomass or light intensity (Perkins et al. pers. obs.). This pattern remains to be further investigated.

In conclusion, the data presented in this study demonstrate that PS I fluorescence introduces an error into the calculated value of ETR. Although most of the PS I fluorescence can be removed from the overall signal by using a $680 \mathrm{~nm}$ bandpass filter, this introduces a second error (which operates in the opposite direction) by giving undue weighting to fluorescence from cells at the surface of the biofilm. Consequently, there is no clear advantage to using the $680 \mathrm{~nm}$ bandpass filter with an integrating fluorometer, such as the Xenon PAM system used in this study. In many situations, a more substantial source of error than PS I fluorescence is the vertical migration of cells within biofilms, which can have an enormous impact on the calculated value of ETR and, consequently, on estimates of primary production within biofilms. While these data do not rule out the application of chlorophyll fluorometry to the estimation of ETR and rates of primary production within biofilms, they do present a very clear demonstration of how important it is to know the vertical location of cells within the biofilm and to be able to measure values of $F_{\mathrm{q}}{ }^{\prime} / F_{\mathrm{m}}$ ' from individual cells. This can be realistically achieved only when using high resolution imaging of chlorophyll fluorescence.

Acknowledgements. This work was funded by NERC grant GR3/11782. A.R.M.H. was supported by a NERC Environmental Diagnostics CASE studentship, ref. GT/22/96/ENVD/5.

\section{LITERATURE CITED}

Barranguet C, Kromkamp J (2000) Estimating primary production rates from photosynthetic electron transport in estuarine microphytobenthos. Mar Ecol Prog Ser 204:39-52

Dau H (1994) Molecular mechanisms and quantitative models of variable photosystem II fluorescence. Photochem Photobiol 60:1-23

Decho AW (1990) Microbial exopolymer secretions in ocean environments: their role(s) in food webs and marine processes. Oceanogr Mar Biol Annu Rev 28:73-153

di Marco G, Manes FS, Tricoli D, Vitale E (1990) Fluorescence parameters measured concurrently with net photosynthesis to investigate chloroplastic $\mathrm{CO}_{2}$ concentration in leaves of Quercus silex L. J Plant Physiol 136:538-543

Dong LF, Thornton DCO, Nedwell DB, Underwood GJC (2000) Denitrification in sediments of the river Colne estuary, England. Mar Ecol Prog Ser 203:109-122

Eaton JW, Moss B (1966) The estimation of numbers and pigment content in epipelic algal populations. Limnol Oceanogr 11:584-595

Edwards GE, Baker NR (1993) Can $\mathrm{CO}_{2}$ assimilation in maize leaves be predicted accurately from chlorophyll fluorescence analysis? Photosynth Res 37:89-102

Flameling IA, Kromkamp J (1998) Light dependence of quantum yields for PSII charge separation and oxygen evolution in eucaryotic algae. Limnol Oceanogr 43:284-297

Genty B, Briantais JM, Baker NR (1989) The relationship between the quantum yield of photosynthetic electron transport and quenching of chlorophyll fluorescence. Biochim Biophys Acta 990:87-92

Genty B, Wonders J, Baker NR (1990) Non-photochemical quenching of $F_{o}$ in leaves is emission wavelength dependent: consequences for quenching analysis and its interpretation. Photosynth Res 26:133-139

Genty B, Goulas Y, Dimon B, Peltier G, Briantais JM, Moya I (1992) Modulation of efficiency of primary conversion in leaves, mechanisms involved at PSII. In: Murata N (ed) Research in photosynthesis, Vol IV. Kluwer Academic Publishers, Dordrecht, p 603-610

Guillard RRL, Ryther JH (1962) Studies of marine planktonic diatoms. I. Cyclotella nana Hustedt, and Detonula confervacea (Cleve) Gran. Can J Microbiol 8:229-239

Hartig P, Wolfstein K, Lippemeier S, Colijn F (1998) Photosynthetic activity of natural microphytobenthos populations measured by fluorescence (PAM) and ${ }^{14} \mathrm{C}$-tracer methods: a comparison. Mar Ecol Prog Ser 166:53-62

Havaux M, Strasser RJ, Greppin H (1991) Effect of incident light intensity on the yield of steady-state chlorophyll fluorescence in intact leaves. An example of bioenergetic homeostasis. Environ Exp Bot 31:23-32

Krall JP, Edwards GE (1990) Quantum yields of photosystem II electron transport and carbon dioxide fixation in $\mathrm{C} 4$ plants. Aust J Plant Physiol 17:579-588

Kromkamp J, Barranguet C, Peene J (1998) Determination of microphytobenthos PS II quantum efficiency and photosynthetic activity by means of variable chlorophyll fluorescence. Mar Ecol Prog Ser 162:45-55

Laisk A, Oja V, Rasulov B, Eichelmann H, Sumberg A (1997) Quantum yields and rate constants of photochemical and non-photochemical excitation quenching-experiment and model. Plant Physiol 115:803-815

Long SP, Hällgren JE (1993) Measurement of $\mathrm{CO}_{2}$ assimilation by plants in the field and laboratory. In: Hall DO, Scurlock JMO, Bothar-Nordenkamps HR, Leegood RC, Long SP (eds) Photosynthesis and production in a changing environment, a field and laboratory manual. Chapman \& Hall, St. Ives, p1-464

Lorenzen GJ (1967) Determination of chlorophyll and phaeopigments: spectrophotometric equations. Limnol Oceanogr 12:343-346

Oxborough K, Baker NR (1997) An instrument capable of imaging chlorophyll a fluorescence from intact leaves at 
very low irradiance and at cellular and subcellular levels of organization. Plant Cell Environ 20:1473-1483

Oxborough K, Baker NR (2000) An evaluation of the potential triggers of photoinactivation of photosystem II in the context of a Stern-Volmer model for down-regulation and the reversible radical pair equilibrium model. Phil Trans R Soc Biol Sci 355:1489-1498

Oxborough K, Hanlon ARM, Underwood GJC, Baker NR (2000) In vivo estimation of the photosystem II photochemical efficiency of individual microphytobenthic cells using high-resolution imaging of chlorophyll a fluorescence. Limnol Oceanogr 45:1420-1425

Paterson DM (1989) Short-term changes in the erodibility of intertidal cohesive sediments related to the migratory behaviour of epipelic diatoms. Limnol Oceanogr 34:223-234

Paterson DM, Wiltshire KH, Miles A, Blackburn J, Davidson I, Yates MG, McGrorty S, Eastwood JA (1998) Microbiological mediation of spectral reflectance from intertidal cohesive sediments. Limnol Oceanogr 43:1207-1221

Pfündel E (1998) Estimating the contribution of photosystem I to total leaf chlorophyll fluorescence. Photosynth Res 56: 185-195

Sakshaug E, Bricaud A, Dandonneau Y, Falkowski PG and 5 others (1997) Parameters of photosynthesis: definitions, theory and interpretations of results. J Plankton Res 19: $1637-1670$

Serôdio J, da Silva JM, Catarina F (1997) Non-destructive tracing of migratory rhythms of intertidal benthic microalgae using in vivo chlorophyll a fluorescence. J Phycol 33: 542-553

Editorial responsibility: Otto Kinne (Editor),

Oldendorf/Luhe, Germany
Smith DJ, Underwood GJC (1998) Exopolymer production by intertidal epipelic diatoms. Limnol Oceanogr 43: 1578-1591

Thornton DCO, Underwood GJC, Nedwell DB (1999) Effect of illumination and emersion period on the exchange of ammonium across the estuarine sediment-water interface. Mar Ecol Prog Ser 184:11-20

Underwood GJC, Kromkamp J (1999) Primary production by phytoplankton and microphytobenthos in estuaries. Adv Ecol Res 29:93-153

Underwood GJC, Paterson DM (1993) Seasonal changes in diatom biomass, sediment stability and biogenic stabilisation in the Severn estuary, U.K. J Mar Biol Assoc UK 73:871-887

Underwood GJC, Phillips J, Saunders K (1998) Distribution of estuarine benthic diatom species along salinity and nutrient gradients Eur J Phycol 33:173-183

Underwood GJC, Nilsson C, Sundbäck K, Wulff A (1999) Short-term effects of UVB radiation on chlorophyll fluorescence, biomass, pigments and carbohydrate fractions in a benthic diatom mat. J Phycol 35:656-666

Wolfstein K, Hartig P (1998) The Photosynthetic Light Dispensation System: application to microphytobenthic primary production measurements. Mar Ecol Prog Ser 166: 63-71

Yallop ML, de Winder B, Paterson DM, Stal LJ (1994) Comparative structure, primary production and biogenic stabilisation of cohesive and non-cohesive sediments inhabited by microphytobenthos. Estuar Coast Shelf Sci 39: $565-582$

Submitted: December 12, 2000; Accepted: July 17, 2001

Proofs received from author(s): February 18, 2002 